Hydrol. Earth Syst. Sci. Discuss., doi:10.5194/hess-2016-486, 2016

Manuscript under review for journal Hydrol. Earth Syst. Sci.

Published: 28 September 2016

\title{
Spatial organisation of catchments - assessment and usage for impartial sub-basin ascertainment and classification
}

\author{
Henning Oppel ${ }^{1}$, Andreas Schumann ${ }^{1}$ \\ ${ }^{1}$ Institute of Hydrology, Water Resources Management and Environmental Engineering, Ruhr-University Bochum, Bochum, \\ 5 44801, Germany \\ Correspondence to: Henning Oppel (henning.oppel@rub.de)
}

\begin{abstract}
.
A hydrological model should represent the hydrological most relevant catchment characteristics. These are heterogeneously distributed within a watershed but often interrelated and subject of a certain spatial organisation. In order to reproduce the natural rainfall-runoff response the reduction of variance of catchment properties as well as the incorporation of the spatial organisation of the catchment is desirable. In this study the method of the characteristic structure is introduced to detect and visualize the spatial organisation of catchments, based on stream flow length rearrangement of any catchment feature of interest. Moreover, the method is implemented in an algorithm for automated sub-basin ascertainment, which includes the definition of zones within the newly defined sub-basins. The algorithm is applied on two parameters characterising topography

15 and soil of four mid-European watersheds. Results indicate a wide range of applicability for the method and the algorithm. As a limitation of the application for the algorithm the presence of small scale soil enclosures that do not follow the geomorphologic structure of the catchment could be identified. Finally, results of subdivisions based on soil and topography were intersected to gain insight into catchment organisation. Based on this analysis four types of physiographical types could be established.
\end{abstract}

\section{Introduction}

The identification of landscape units featuring an identical, or at least similar, hydrologic behaviour is a prevailing topic in hydrology. A valid and widely applicable concept is worthwhile for two reasons: for the use in rainfall-runoff-models and the for use in regionalization concepts concerning the prediction in ungauged basins (Sivapalan et al., 2003). Within rainfallrunoff-models these spatial units could define parameter constraints for distributed and semi-distributed models and could, hence, lower the problem of equifinality (Beven, 2006). On the other hand it would enable a profound method for information transfer from gauged to ungauged basins, or could be used as non-Euclidian distance measure to specify the degree of similarity of two catchments (Skøien et al., 2006).

How these units can be identified is, despite all scientific effort, still unresolved. There are several concepts and findings in the scientific literature. The common foundation for all concepts is the interaction of the physiographic and the hydrological 
Hydrol. Earth Syst. Sci. Discuss., doi:10.5194/hess-2016-486, 2016

Manuscript under review for journal Hydrol. Earth Syst. Sci.

Published: 28 September 2016

system within a basin. Winter (2001) expressed that this interaction forms hydrological landscapes, which are defined by landscape, geological framework, climate, surface-, ground- and atmospheric water. The analysis of the hydrologic system is bound to discharge time-series analysis (beside the special case of experimental watersheds) and several catchment classification schemes have been established to identify basins of similar hydrological behaviour (He et al., 2011; Merz and Blöschl, 2003; Sawicz et al., 2011; Wagener et al., 2007). The analysis of the physiographic system is more critical than the analysis of the hydrologic system since the driving catchment features responsible for its function are unknown. Studies have shown that catchments with similar soil and topographical values are featuring similar rainfall-runoff dynamics (Müller et al., 2009; Güntner et al., 2004) and therefore most classification schemes try to combine these features (Müller et al., 2009; Dunn and Lilly, 2001; Soulsby et al., 2006). However, these strategies are mostly restricted to a single characteristic. Sivapalan

10 (2005) pointed out that the organisation of a catchment is the fundamental influence on the hydrologic system. Patterns of symmetry between soil, topography and the stream network could give insight to underlying mechanisms that induce discharge behaviour. Well known methods to assess the organisation are mainly based on the stream network (Rodríguez-Iturbe and Valdés, 1979; Verdin and Verdin, 1999; Skøien et al., 2006). But these methods neglect information about interdependencies between soil and topography of the catchment. The heights above the nearest drainage concept and classification scheme by

15 Nobre et al. (2011) Gharari et al. (2011) and Savenije (2010) takes the geomorphologic allocation of basins cells into account and defines hydrological response units (HRU). This concept does account for soil, topography and their interaction but omits the exact location and possible interactions along the flow path within a basin.

The purpose of this study is to develop methods for impartial und automated definition of sub-basins for modelling purposes and to describe physiographical similarities for these sub-basins. Both methods are supposed to consider the spatial 20 organisation of catchments and utilize topographic as well as soil data. At first, we will introduce the method of characteristic structure. For a given catchment characteristic, values are reorganized by their interaction with the flow paths within the basin. With this analysis we are able to assess the succession of the analysed characteristic and the occurrence of regions comprising high or low variance. With the connection to the flow path this analysis brings insight to processes of lateral flow distribution (Grayson and Blöschl, 2001). In contrast to classic methods for spatial pattern evaluation (like Point-by-Point or optimal logical

25 alignment methods (Grayson and Blöschl, 2001)) the new method retains information about location and position in the succession of catchment characteristics along the flow path axis.

Using this method as a foundation, an algorithm is established to subdivide a basin into several sub-basins in order to reduce the heterogeneity of a given characteristic and reproduce its spatial organisation. Please note that we define sub-basins in the sense of Lindström et al. (1997) as closed hydrological units. Transferred to a hydrological model these sub-basins could be 30 used as individual instances and can be linked via flood routing methods.

The introduced algorithm incorporates three different techniques for spatial subdivision of a watershed, based on an objective function. The latter identifies regions within a catchment that comprise high variance of a specific catchment characteristic and indicates the need for reduction. With use of three techniques called separation, subdivision at ramifications and zonal 
Hydrol. Earth Syst. Sci. Discuss., doi:10.5194/hess-2016-486, 2016

Manuscript under review for journal Hydrol. Earth Syst. Sci.

Published: 28 September 2016

(c) Author(s) 2016. CC-BY 3.0 License.

classification this target can be achieved. Each technique is distinctly usable but are used here in succession or in competition to each other in the proposed algorithm.

Results of this algorithm can be used as spatial units for a semi-distributed hydrological model, or via classification for regionalization. In this study we applied the algorithm on four meso-scale catchments in central Europe on characteristics of

5 topography and soil. Results were used to develop four distinct physiographical types. Section 2 will introduce the developed methods and used data. Section 3 presents the results of application. Discussion of obtained results and physiographical types will be presented in Sect. 4. Final conclusions and outlook will be given in Sect. 5.

\section{Methods and Data}

\subsection{Data}

10 Four catchments were chosen for application. The basin of the Mulde (Fig. 1, lower right) is located mostly in eastern Germany and with a small part in north Czech. It covers the mid-range mountainous region of the Ore Mountains in the south and the Mulde Loess Loam Hills in the north. With a size of $6170 \mathrm{~km}^{2}$ it is the largest catchment used in this study. Located in the Bohemain Forest in west Bavaria, the catchment of the river Regen (Fig. 1 upper left) is with a size of $2613 \mathrm{~km}^{2}$ the smallest river basin used for application. The headwater catchment of the Main (Fig. 1, upper right), including the White and Red Main

15 comprises an area of $4224 \mathrm{~km}^{2}$. Last selected catchment is an alpine catchment with similar size to the Mulde, the catchment of the Salzach in Salzburg, Austria, comprising an area of $5995 \mathrm{~km}^{2}$. All catchment own different geomorphologic structures and river network types. While in the first three catchments, higher mountains are nearly exclusively located at the outer watershed of the catchment, the Salzach catchments contains three big mountains located at the centre of the catchment. The two main tributaries encompass these mountains. While the basin of the Mulde has a nearly continuous increase of slope and

20 heights from north to south, the topography of the remaining catchments is much more heterogeneous. For the proposed methods and algorithm at least a digital elevation model (DEM) is essential. For this study we used a gridded DEM derived from the Shuttle Radar Topography Mission (SRTM) with a regular 100 meter resolution. By means of the D8algorithm the required data like flow directions, flow length and flow accumulation were calculated (Jenson and Domingue, 1988). For the catchment of the Mulde a proved digital river network was available. Stream networks of the remaining basins

25 were calculated via flow accumulation algorithms. Because it is envisaged to subdivide the presented catchments by soil characteristics, a gridded soil data map by the German Federal Institute for Geosciences and Natural Resources (BÜK200) and CORINE land coverage data (CLC) (Bossard et al., 2000) were used. Pedo-transfer functions (Sponagel, 2005) combined these information into gridded data about (available) water capacities, hydraulic conductivities and other characteristics. In case of the Salzach basin precast pore volume data for the LARSIM-ME model were used, due to a lack of soil data (Bremicker, 2016).

30 Pore volume data is depicted in Fig. 2 for watersheds of the Main, Regen and Salzach. Data for the Mulde basin is shown in Fig. 3. Beside the mentioned topographical structure of the basin we can now see similarities and differences in the pedologic system. The dependency of pore volume and heights is common for all basins, mountainous regions tend to have lower values 
Hydrol. Earth Syst. Sci. Discuss., doi:10.5194/hess-2016-486, 2016

than flat lands. A main difference is the arrangement of higher values. While in the Salzach catchment only mid-range values align around the streams and only smaller spots of higher values are present, the catchment of the Mulde has a break between high and low values in the centre of the basin. Moreover, wide soil belts with high pore volume encompass the river valleys in transition area. In comparison to these pattern, soils in the Regen and Main basin seem nearly homogenous with respect to some stripes of higher values near the outlet of the basins.

\subsection{Characteristic structures}

We defined the spatial organisation of a catchments by analysing the succession of values of selected catchment characteristics along the flow path of a catchment. The flow length within the catchment is evaluated by a pathway oriented search. The lateral flow lengths are divided into flow lengths within the river network to the outlet (called stream flow length (SFL)) and along

10 the land surface to the next stream cell (defined as over land flow length (OFL)). Note that the perspective is set upstream.

To evaluate the characteristic structures of a catchment characteristic, their values within each grid cell were combined with their SFL and OFL data. Since distances are not continuous, due to the gridded data and depending on grid size, distances were ordered into classes. Therefore width of $\Delta \mathrm{s}$ for SFL- and $\Delta \mathrm{o}$ for OFL classes have to be defined. The basin is thereafter treated as a succession of SFL-classes and OFL-classes.

15 All grid-cells of the catchment are merged in their respective class by following routine: all cells feature an SFL value greater or equal than (i-1). $\Delta \mathrm{s}$ and smaller than $\mathrm{i} \cdot \Delta \mathrm{s}$ are drawn into the cluster $\mathrm{i}$, where $\mathrm{i}$ is an integer and raised from one until no cells unassigned are left. For the presented catchments a value for $\Delta \mathrm{s}$ in a range from 1 to $10 \mathrm{~km}$ proved to be most adequate. For each SFL-class an average value and standard deviation of the characteristic of interest within the distance class can be calculated:

$20 \quad \bar{X}_{s f l}=\frac{1}{n_{\text {Cells;sfl }}} \sum_{j=0}^{n_{\text {Cells } s \text { s }}} X_{j}$

$\sigma_{s f l}=\sqrt{\frac{1}{n_{\text {Cells } ; s f l}-1} \sum_{j=1}^{n_{\text {Cells } s \text { fl }}}\left(\mathrm{X}_{j}-\overline{\mathrm{X}}_{\mathrm{j}}\right)^{2}}$

where sfl indicates the SFL-class, $\mathrm{n}_{\text {Cells,sfl }}$ is the number of cells assigned to this class and $\mathrm{X}$ is the characteristic of interest. If the average and the standard deviation of each class is plotted against its average distance to the outlet, the characteristic structure of the catchments is made visible. As an example Fig. 3 shows the available water capacity (AWC) in the Mulde catchment and its characteristic structure (with $\Delta \mathrm{s}=1 \mathrm{~km}$ ).

An amplification of this method is to take the OFL-classes into account. By their distance to the next stream it is possible to distinguish between regions which are close to stream or more distant and to evaluate the catchment characteristic for these regions separately. In Fig. 4 the characteristic structure of AWC is separated by distance classes of OFL. Instead of the one- $\sigma$ range, averages of OFL-classes are depicted. From these analysis one might conclude that the variance in the SFL classes (in

30 Fig.3) is mainly caused by differences of AWC according to the distance from stream cells. 
Hydrol. Earth Syst. Sci. Discuss., doi:10.5194/hess-2016-486, 2016

Manuscript under review for journal Hydrol. Earth Syst. Sci.

Published: 28 September 2016

Note that the method can be applied to all gridded data with a metric scale (soil, climate, topography, etc.). Moreover, it is possible to identify shifts of means and variance along the flow path and can allocate their placement within the catchment.

\subsection{An algorithm for automated sub-basin ascertainment}

If we assume that the aim of sub-basin ascertainment is to reduce heterogeneity within the watershed, it is obvious that the method of characteristic structures is a convenient tool for this target. Shifts of variance along the SFL-axis and high variance regions can be interpreted as regions within a catchment that need to be subdivided into sub-basins. From the characteristic structure in Fig. 3 we can derive several cases that need to be handled by an algorithm for sub-basin ascertainment:

1. Presence of low variance regions and high variance regions: it is expedient to separate low variance regions from the high variance regions because the former do not require further handling.

2. Presence of high variance regions solely: the basin needs to be subdivided in order to decrease the heterogeneity.

3. Presence of low variance regions: no action required.

For separation, two tools and an objective function had to be developed. Task of the objective function is to identify high and low variance regions. For this purpose it utilizes the method of characteristic structures, as described above. A tool for separation of low variance regions needs to allocate the drainage point of target areas, marked by values of the objective function below a certain threshold. For the reduction of variance in high variance regions we developed two strategies that are conducted in competition. The first strategy proceeds the subdivision by the identification of confluences, or in this case ramifications, because we are looking upstream. This strategy aims to subdivide a basin by its river network. Second strategy is the definition of zones without the definition of additional sub-basins. Two zone types were introduced: close to stream (indicating wetlands) and far from stream (indicating hillslopes). The definition of zones is bound the river network and the

20 OFL data.

All tools are introduced in the following sections. For better understanding their procedures are demonstrated for a synthetic catchment shown in Fig. 5. On the left of Fig. 5 flow directions and Strahler orders are shown, in the middle the SFL data and the SFL-class (here the width of the classes is set to 5) and on the right an arbitrary input variable is shown. After the introduction of the developed tools the sequence of the ACS (Ascertainment by Characteristic Structure) algorithm will be illustrated.

\subsubsection{Objective Function}

The value of the objective function is calculated from the characteristic structure of the standard deviation $\sigma$, shown in Fig. 6 . (Additionally the standard deviation is shown for two different values of $\Delta \mathrm{s}$ ). A casual observer will easily spot regions with higher $\sigma$ that should be considered for ascertainment. To make this feasible for the ACS a threshold value $\Omega$ has been introduced that states whether a SFL-class is to file as "low" or as "high" variance class. This is derived from the data by: 
Hydrol. Earth Syst. Sci. Discuss., doi:10.5194/hess-2016-486, 2016

Manuscript under review for journal Hydrol. Earth Syst. Sci.

Published: 28 September 2016

(c) Author(s) 2016. CC-BY 3.0 License.

$\Omega=\frac{\sum_{j=0}^{N_{s f l}} \omega_{j}{ }^{e} \cdot \sigma_{j}}{\sum_{j=0}^{N_{s f l}} \omega_{j}}$

where $\mathrm{N}_{\mathrm{sfl}}$ is the number of SFL-classes, $\sigma$ is the standard deviation within SFL-class i (Eq. (2)), the exponent e is a variable non-linearity factor and $\omega$ a weighting factor is defined as:

$$
\omega_{j}=\frac{\sigma_{j}-\max _{s f l}(\sigma)}{\min _{s f l}(\sigma)-\max _{s f l}(\sigma)}
$$

5 Coherent SFL-classes above the threshold are considered as high variance regions within the basin that require spatial separation. If regions of SFL-classes below the threshold are found, these regions will be marked as low variance regions. In Fig. 7 two results of an application of the objective function are shown: the first call returns the low variance region in the middle of the catchment and the second call the high variance regions in the lower part.

\subsubsection{Separation algorithm for low variance regions}

10 Low variance regions have no need for further subdivisions. Therefore they are separated from the rest of the basin. Since the exact allocation of these regions is known, all cells within can be defined as target area $\mathrm{T}$ (hatched in Fig. 7, 1.call, left side). Remaining cells are drawn together as non-target area NT. If one random point of the basin is selected as possible separation point (SP) and its watershed is calculated the set of points belonging to the watershed, or sub-basin, of SP, BSP is obtained. The calculated watershed $\mathrm{B}_{\mathrm{SP}}$ covers parts of $\mathrm{T}$ and NT and hence a coverage rate can be calculated as the proportion of the cardinalities of the intersections and their respective superset:

$$
C_{S P}=\frac{\left|B_{S P} \cap T\right|}{|T|}-\frac{\left|B_{S P} \cap N T\right|}{|N T|} \rightarrow \max
$$

The objective of a separation $\mathrm{C}$ is to find a separation point (SP) whose basin $\mathrm{B}_{\mathrm{SP}}$ covers a maximum of $\mathrm{T}$ and a minimum of NT. Please note that for regions located at the outlet of the basin or at its upstream boundary only one SP will be defined. Possible SPs are assumed to be allocated at the transit of the main stream from T to NT, or vice versa. An iterative search returns the coverage values $\mathrm{C}$ and the highest value is selected as SP, defining a new sub-basin. In the upper part of Fig. 7 a concluded separation, as well as the rejected SPs of the iteration (hollow points) are shown.

\subsubsection{Subdivision at confluences/ramifications}

Because the chosen perspective is upstream, the ACS is searching for ramifications of the river network, where a main river splits into two tributaries. To identify ramifications the characteristic structure of flow accumulation (FAcc) is examined. Since 
Hydrol. Earth Syst. Sci. Discuss., doi:10.5194/hess-2016-486, 2016

the FAcc indicates the contributing drainage area to each stream cell, discontinuities in the characteristic structure, which is the succession of the FAcc values, will reveal confluences of streams.

Figure 7 shows an example for the Mulde. Beginning at the Outlet (zero on the x-axis) two features are visible: a slowly decreasing line of high FAcc values, representing the main stream at the outlet, and a noise-like smaller range of FAcc values close to the abscise, caused by the smaller tributary streams and contributing areas. To identify major tributaries this noise has to be removed. We assume that in the first distance class the disparity between main rivers and contributing hillslopes is most distinct. Within the first SFL-class a k-Means cluster analysis is carried out to divide high and low FAcc values. Threshold value $\tau_{\mathrm{S}}$ is determined as:

$$
\tau_{S}=\min _{c}\left[\max _{c 1}[F A c c] ; \max _{c 2}[F A c c]\right] \cdot\left(1-\frac{i}{10}\right)
$$

10 where $\mathrm{c}$ indicates the clusters and $\mathrm{i}$ is the reduction order and by default 0 . The algorithm will start with the default value for $\mathrm{i}$ and searches for the first ramification in upstream direction. If no ramification is found, order $\mathrm{i}$ is increased by 1 . The maximum order is set to 10. Please note that the higher i is set, the lower the threshold gets and more FAcc-values remain for analysis. The routine identifies the coordinates of the ramification inducing the drop in FAcc values (see Fig. 8, for example at SFL $\approx$ $80 \mathrm{~km}$ ). Two new drainage points are set at the ramification, defining the new sub-basins. The subdivision of a synthetic catchment is shown in Fig. 7 (lower middle).

\subsubsection{Zonal classification}

Another way to subdivide a high variance region without setting new separation points is to split the cells within the region, i.e. the catchment into zones. This is comparable to the concept of HRUs. But, in this case we take the allocation of each cell and its position along the SFL-axis into account. Therefore, only two possible types were implemented: "close to stream" and "far from stream" cells. For some catchment characteristics these zone might comply with natural wetlands and hillslopes, but is not compulsory for all possible input data.

To identify close to stream cells, firstly the stream has to be selected. Since, we try to emulate natural patterns of the input data not all present stream cells might be relevant. We assume that we need to separate data fields around higher order streams from data fields located at lower order streams. Therefore, streams are selected by their Strahler order. Cells draining into the selected stream cells, with an OFL value equal or below a threshold $\Delta \mathrm{o}$, are defined as "close to stream" cells. Remaining cells are marked as "far from stream".

Because we do not know the dominant spatial pattern of the input data the search for an optimal extent of the "close to stream" zone is done iteratively. The iteration employs two variables: the reduction of the Strahler order $\mathrm{s}_{\mathrm{R}}$ from the maximum occurring Strahler order $\mathrm{M}_{\mathrm{S}}$ and the width of the zones $\Delta \mathrm{o}$, expressed as multiple of cell width. Parameter ranges are [0; $\mathrm{M}_{\mathrm{S}^{-}}$

$301]$ for $S_{R}$ and $[0,5]$ for $\Delta$ o, respectively. Cells draining into streams cells with Strahler order equal or lower than $M_{S}-S_{R}$ and an OFL value equal or lower than $\Delta \mathrm{o} \cdot \Delta \mathrm{x}$ are marked as "close to stream". In Fig. 9 a sequence of the iteration is shown for the 
Hydrol. Earth Syst. Sci. Discuss., doi:10.5194/hess-2016-486, 2016

Manuscript under review for journal Hydrol. Earth Syst. Sci.

Published: 28 September 2016

entire synthetic catchment. After each iteration, the standard deviation $\sigma$ (Eq. (2)) is calculated for each zone and subsequently averaged. The parameter combination $\left(\mathrm{s}_{\mathrm{R}}, \Delta \mathrm{o}\right)$ with the lowest averaged standard deviation is chosen for final classification. In Figure 6, an example for a chosen zonal classification for the synthetic catchment is shown. The ACS will define results of the technique leading to the highest reduction of the standard deviation $\sigma$ as superior and omits the inferior result.

5 Please note that the algorithm has the possibility to neglect the usage of zonal classification. If the calculated averaged $\sigma$ of the zones is equal to or higher than $\sigma$ of the unseparated data, the whole basin will be marked as zone type "none".

\subsubsection{Sequence of the ACS-algorithm}

Now that we have introduced all necessary tools we have to compile them into an algorithm that will ascertain sub-basins automatically. At first the targets and restrictions for the ascertainment have be defined: The main target was set to minimise $\sigma$ of the considered feature which is expressed in the objective function. We posit that shifts and breaks in the average of the characteristics along the SFL-axis can be compensated within the (rainfall-runoff) model structure using the obtained catchment subdivision. Furthermore the capability to make use of HRUs or zones within each sub-basin is presumed, although the latter presumption is not mandatory. An additional assumption is that the consideration of major streams within a model structure is worthwhile, independent from variance compulsion. In the completed algorithm the separation of major streams is made an optional choice. Major streams, or major stream ramifications are identified likewise to any other ramification (Sect. 2.3.3), but additionally the FAcc value of the tributary stream has to be higher than the threshold value $\tau_{R}$. This parameter is calculated as percentage of the maximum FAcc value in the basin (e.g. 5\%) once at the initialisation of the algorithm.

Figure 10 shows the implemented sequence of the algorithm as a flow chart, as a result of the following considerations:

1. If a major ramification is present, the subdivision at ramification is activated without calling the objective function.

2. The presence of low variance regions requires their separation from the remaining regions and is succeeded preliminary to subdivision.

3. In case of present high variance regions solely, results of the subdivision technique yielding a lower averaged value of $\sigma$ will be saved, other results will be discarded.

4. In order to obtain a consistent results, zonal classification is called additionally in case only low variance regions are present. Thereby, independent from the need of $\sigma$ reduction, all ascertained sub-basins will comprise a zonal classification.

Beginning at the outlet of the entire catchment ACS will check at first if a major ramification is present in the catchment (if activated). This being the case, the subdivision at ramification is activated (Sect. 2.3.3) and two new sub-basins are obtained and are stored. Now the basin between the initial outlet point and the newly defined separation points will be analysed again.

30 The objective function (Sect. 2.3.1) is called and based on its answer decided if a partition is required. If high variance regions are present in the basin actions of sub-basin ascertainment are necessary. Conditional to the presence of low variance regions separation tool (Sect. 2.2.2) or separation tools are called. Otherwise the supplementary zones are calculated (Sect. 2.3.4) and the next basin is analysed. 
Hydrol. Earth Syst. Sci. Discuss., doi:10.5194/hess-2016-486, 2016

\section{Results}

Sub-basin ascertainment has been carried out on two characteristics: pore volume (total pore volume for Mulde, Regen and Main, AWC for Salzach (due to data availability, compare Fig. 2 \& Fig. 3)) and surface slope. Please note that that both applications and, hence, their results are disjoint.

5 In order to evaluate the success of the applications we have to compare $\sigma$ before separation (U) and $\sigma$ after separation (S) for the entire catchment. In case of $\sigma(\mathrm{U})$ Eq. (2) can be applied without modifications. For $\sigma(\mathrm{S})$ we have to account for the succeeded sub-division of the catchment. If within a SFL-distance class (of the entire catchment) neighbouring sub-basins are present, $\sigma$ is calculated individually for each sub-basin and afterwards $\sigma(\mathrm{S})$ for the entire SFL-class is calculated as area weighted average of these $\sigma$ values.

10 Sub-basins and zones for all basins and applications are depicted Fig. 11. The characteristic structure of $\sigma(\mathrm{U})$ (blue lines) and $\sigma(\mathrm{S})$ (red lines) as well as threshold $\Omega$ (according to Eq.(3)) for different weightings $\mathrm{e}=0, \mathrm{e}=0.5$ and $\mathrm{e}=1$ are shown. Outlets of the defined sub-basins are classified by their derivation. Drainage points at major ramifications are depicted as black triangles, while blue dots indicate points for separation of low variance regions and subdivisions at ramifications with order 1. These points are merged as category 1 points. Category 2 points indicate points of subdivision of higher order and hence

15 indicate the separation of smaller contributing streams.

Although the success and differences between the outcomes of the algorithm are visible, we are not able to quantify these observations. To make our results commensurable two numerical measures of success were developed. Both measures are based on the objective function that implies a minimisation of $\sigma$. This can be expressed as the subtraction of $\sigma(\mathrm{U})$ and $\sigma(\mathrm{S})$. To account for different expected values of the input data (in this case for slope than for storage) the reduction of $\sigma$ is normalized by the used threshold $\Omega$. The first measure is the total reduction $\alpha_{1}$ :

$$
\alpha_{1}=\frac{\sum_{j=0}^{n_{s f l}} \sigma_{j}(U)-\sigma_{j}(S)}{\Omega}
$$

The second measure was defined as the reduction of $\sigma$ below the threshold $\Omega$. This indicator tells if the target has been achieved just scantly or more solid. Only distance-classes that have reached $\Omega$ are taken into account for this measure. The set of distance-classes fulfilling this requirement can be written as:

$z=\left[j_{s f f i: 1}, \ldots j_{s f f ; n} \mid \sigma_{j} \leq \Omega\right]$

Then $\alpha_{2}$ can then be written as the reduction of $\sigma$ in the set of distance-classes z:

$$
\alpha_{2}=\frac{\sum_{z} \sigma_{z}(U)-\sigma_{z}(S)}{\Omega}
$$

A summary of the results is given in Table 1. From this table and Fig. 11 we can see that some applications were more successful than others, e.g. application on slope data in the Regen catchment (nearly all classes below threshold, highest $\alpha_{2}$ ) 
Hydrol. Earth Syst. Sci. Discuss., doi:10.5194/hess-2016-486, 2016

Manuscript under review for journal Hydrol. Earth Syst. Sci.

Published: 28 September 2016

compared to slope for the Mulde (nearly no reduction). The density of close to stream zones is comparable for all basins, it ranges from $18-25 \%$ for pore volume and $22-30 \%$ for slope.

However, the application on pore volume in the Mulde catchment resulted in the highest success rates $\alpha_{1}$ and $\alpha_{2}$ which is only overcome by the success in the Main catchment. Here we obtained only a small total reduction, but the reduction below $\Omega$ is

5 superior to all other applications. The lowest pore volume success can be seen in the Regen catchment. Another striking result is the outcome in the Salzach catchment. For pore volume, the highest total reduction is achieved, but only little reduction below $\Omega$. On the other side application on slope led to high success rated (both measures). These results do not directly indicate that the outcome of the algorithm is bound a specific parameter, hence good and bad results are obtained for both features and different catchments.

\section{Discussion}

\subsection{Limiting factors for the algorithm}

Lowest success rates are achieved in the application on slope in the Mulde and pore volume in the Regen catchment. Additionally $\alpha_{1}$ of pore volume application in the Salzach catchment is high, but the reduction of $\sigma$ below the benchmark $\Omega$ is low. Because the low success rates are not limited to one catchment, or to one specific feature it cannot be conducted that a

15 single catchment structure or a single feature is responsible for inferior outcome. Possible alternative explanatory factors are the geomorphologic structure and/or the specific values of the considered features.

To gain more insight on this topic a resampling experiment has been performed. Aiming to examine structural identical catchments with a different range of featured values. Accounted by their similar size, the Mulde and the Salzach catchment were chosen for resampling. Each cell of the DEM and AWC data has been ranked and cell values were exchanged according

20 to their rank. Shifting the alpine structure of the Salzach to soil and heights of the Ore Mountains, and the middle mountainous structure of the Mulde to an alpine soil and topography. Resampled AWC values are shown Fig. 12. Stream network, SFL- and slope values were recalculated for the new DEM. Afterwards the resampled basins were used for sub-basin ascertainment. Results are shown in Fig. 13 and the success rates are given in Table 2.

One of the least successful separations has been the subdivision of the original Salzach catchment by pore volume. After 25 resampling, the same geomorphologic structure with the AWC values of the Mulde basin reaches much higher, in case of $\alpha_{2}$ the highest, success rates. On the other side, separation based on resampled slope (derived from resampled DEM) improved for both catchments. This results strengthens the thesis that geomorphologic structure and the individual values are the key factors. If the original DEM values (Fig 1) and the original and resampled AWC values (Fig. 2, 3, 12) are compared, the argumentation gets clearer: In case of the pore volume, small spots comprising much higher values than their surrounding area

30 in both catchments are visible. Like enclosures in material sciences, these spots can be considered as soil enclosures within the catchment that do not follow the geomorphologic co-evolutional structure (Blöschl et al., 2013) of the basin. 
Hydrol. Earth Syst. Sci. Discuss., doi:10.5194/hess-2016-486, 2016

Manuscript under review for journal Hydrol. Earth Syst. Sci.

Published: 28 September 2016

Figure 14 shows a map of (original) AWC in the Salzach catchment in a larger scale and the regions with enclosures are marked, in the resampled Mulde catchment these spots are best visible in Fig. 12, located in the upper region on the right boundary of catchment. Moreover these enclosures are clearly visible in the characteristic structure of $\sigma$ (Fig 11 and Fig.13). Following this results and conclusions, the first limitation can be stated: enclosure of values that do not follow the flow path

5 arrangement of the catchment lower the ascertainment success rate.

If this hypothesis is true, then it brings another question: why has the ACS worked so well in the original Mulde catchment? Despite the presence of enclosures, which were part of the original structure that has been retained through the resampling process, high $\alpha_{1}$ values were obtained. The only reasonable explanation is the difference of absolute values between the enclosures and the surrounding areas. Since the range of AWC of the Salzach is higher, the difference has been increased

10 through the resampling process. This is also the case for the DEM and hence the slope. These facts lead to the following conclusion: The higher the difference the lower the success rate.

Another striking observation pointed out before is the success for slope in the original and resampled catchments. Following the beforehand conclusion, an explanation can be given: In the Salzach catchments the range of the DEM is very high and, as it can be seen in Fig. 1, the change from higher regions to lower regions is commonly on short distance. Results from the

15 original application show that the algorithm is working well on this setting, but its success is increased if the difference between high and low elevation values is lowered. It is the other way around for the catchment of the Mulde. Elevation and slope are highly dependent on the distance from the outlet and $\sigma$ rises with increasing SFL nearly continuous. Discontinuities between the distance classes seem to be too small for the algorithm to detect.

The resampling experiment showed that if the difference of the values is increased, the success of the algorithm is increased

20 as well.

\subsection{Spatial extend of zones}

Although the subdivision and separation tools are, in the sense of $\sigma$-reduction, mostly superior to zonal classification (what can be concluded from the high number of performed sub-divisions and, in relation to the initial basins, small sub-basins) a look at the spatial extend of zones is worthwhile. For this analysis we are looking at the "close to stream" zones, since "far from stream" zones are calculated as remaining cells. In the results (Table 1 and Fig. 11) we can see that the average extent of "close to stream" zones is similar in all catchments and for both applications. Nevertheless, differences are visible between the sub-basins. Neighbouring and nested sub-basins reveal in some cases major differences although their spatial allocation might suggest different. While some sub-basins are separated in small close to stream belts around the major streams and large "far from stream" zones, others incorporate extensive "close to stream" zones. The zone densities, calculated as the proportion of

30 "close to stream" zones of the entire (sub-)basin, within all applications have an average of $24 \%$ but the range of densities moves from $0.5 \%$ to $67 \%$. This observations leads to a fundamental question: Which physiographic property of the sub-basins regulates extend of these zones? 
Hydrol. Earth Syst. Sci. Discuss., doi:10.5194/hess-2016-486, 2016

Manuscript under review for journal Hydrol. Earth Syst. Sci.

Published: 28 September 2016

To answer this question we have to look into more detail of the results. Since the target of zonal classification is to reduce $\sigma$ of the sub-basin by separating into two sets of values, there are two ways to cope with this task. Either the "close to stream" zone tries to cover as much cells as possible with a minimum of variance, or it tries to embrace regions of the sub-basin casing the highest variance with a minimum of coverage. These two operations of zonal classification can be called "Minimisation"

5 and "Maximisation". In Fig. 15 the usage of these operations is shown on the example of the Mulde. As it can be seen extend of zones is not bound to the operation. If we now take the relationship of $\sigma$ in "close to -" and "far from stream" into account, see Fig. 16, a pattern becomes visible. While narrow zone belts around the stream tend to have a significant difference of $\sigma$, extensive zone are mostly present if $\sigma$ values are not widespread. Results of the other basins imply identical interpretations.

These findings can answer our initial question: Extend of zones is bound to the presence of patterns around the major streams within a catchment. In the absence of a clear stream orientated pattern, "close to stream" zone get more extensive.

\subsection{Definition of physiographical types}

With the use of the proposed method of characteristic structure and the ACS-algorithm we have obtained spatial subdivisions for each catchment and each catchment feature. Now we have to find a way to combine these results and to assess the question what these results tell about the spatial organisation of these catchments. The simplest way to combine the outcome of different input data and retain the univariate objective function is to run the algorithm in turn over all input data and use ascertained sub-basins as pre-subdivision. Afterwards a combined set of sub-basins is obtained that accounts for all input data. In order to obtain zones for these sub-basins, the algorithm has to be rerun for all input data, using the beforehand obtained sub-basins. Individual zone networks are available for each catchment feature after this procedure.

To combine them it seems worthwhile to overlay the obtained data sets. Figure 16 shows the overlay of zones for slope (yellow)

20 and pore volume (blue) for all catchments used in this study. Intersecting zones appear greenish. It is now up to the user to decide how these zones are combined. Either they can be combined through logical operators (intersection or union) or as weighted averages by means of weights of the input data or by the reduction of variance of each zone.

Beside the combination of zones we can use them for the assessment of spatial organisation of catchments. After the application of the algorithm we assume that each sub-basin certainly represents a homogeneous natural unit. The defined zones indicate the structure of the input data with respect to drainage system within this unit. Following the definition of Winter (2001) a hydrological landscape is determined by the interaction of a physiographic feature and the hydrologic system. The physiographic part is defined by its land surface form, the geological system and its climate. The hydrologic system defined by surface, ground and atmospheric water.

With the conducted case studies, we are able to use the slope data as information about the flow energy and the pore volumes

30 as information about the pedologic system and, hence, are able to identify physiographical types.

If Fig. 16 (left side) is examined with this perspective four types of zonal intersections are visible:

- Type A: Narrow slope and pore belts. Soil is arranged in valleys along main rivers. Especially visible in map excerpt A in Fig. 16 (right side). 
Hydrol. Earth Syst. Sci. Discuss., doi:10.5194/hess-2016-486, 2016

- Type B: Soil belts and extensive slope zones. Soil patterns are bound the drainage system, with disseminated sidearm valleys, or plains.

- Type C: Slope belts and extensive soil zones. Valleys around the main rivers with similar to hillslope soils.

- Type D: Plains or disseminated side-arm valleys with no predominant soil pattern. Shown in map excerpt B in Fig. 16 (right side).

In map excerpt A in Fig. 16 we can see a wide valley, with sloping hillsides, the AWC follows this patterns with higher values in the stream valley. "Close to stream" zone densities (left side of Fig. 16) are low and shaped like a single line. In contrast, map excerpt B shows a shallower, disseminated valley with no soil pattern. These two excerpts are good examples for Type A and D sub-basins.

10 To differentiate between high and low density a k-means analysis for zone densities has been carried out for all four catchments. Boundary values were found in a range from $22 \%$ to $27 \%$ zone density. A scatterplot of zone densities in the Salzach catchment and the calculated k-means boundaries are shown in Fig. 17. The four sectors can be interpreted as the four defined physiographical types: Type A in the lower left, Type B upper left, Type $\mathrm{C}$ lower right and Type $\mathrm{D}$ in the upper right.

This classification schemes has been applied to all catchments. The obtained maps of present physiographical types are shown

15 in Figure 18. In the Mulde catchment types A and B are predominant while in the Regen catchment type B is dominant solely. While the Main catchment is dominated by $\mathrm{C}$ and $\mathrm{D}$ types, the Salzach catchment is split into a Type A dominated part and mixed section.

\section{Conclusions}

The purpose of this study was to assess the spatial organisation of catchments and to utilize extracted information for impartial

20 and automated subdivision of catchments. Moreover, we aimed to value the physiographical similarities between the defined sub-basins. For the assessment of spatial organisation the method of characteristic structures has been introduced and implemented to an algorithm for sub-basin ascertainment. The applicability of the method and the algorithm has been shown for two catchment characteristics, slope and pore volume and four meso-scale watersheds. Results showed that the performed subdivisions delivered a reasonable number of sub-basins and could significantly reduce the heterogeneity of the considered characteristic within these sub-basins. The case studies could not only prove the applicability but also detect some limitations for the ACS-algorithm. The occurrence of soil enclosures, incorporating properties that differ significantly from their surrounding soil, could be identified as interfering. But the occurrence of these enclosures does not always led to significant reduction of the success rate, but rather the heights of the difference between the enclosure and its surrounding were identified to be important. Although these limitations have been identified, the proposed techniques performed well for in our case studies. The usage of ascertained sub-basins in distributed and semi-distributed models will be addressed in upcoming research. In comparison to other methods some advancements of the proposed method and algorithm can be pointed out. First, the underlying method of characteristic structures which accounts for the occurrence of catchment characteristics by their distance 
Hydrol. Earth Syst. Sci. Discuss., doi:10.5194/hess-2016-486, 2016

Manuscript under review for journal Hydrol. Earth Syst. Sci.

Published: 28 September 2016

to the outlet differentiated between stream flow length and over land flow length. This method employs more information about a basin than other common pattern identification schemes, like point-to-point comparisons or optimal logical alignment (Grayson and Blöschl, 2001). Second, the ACS-algorithm incorporates three techniques for sub-basin ascertainment and accounts for the interaction and succession of different catchment characteristics. This is a major advancement to common

5 subdivision methods which are based only on the stream network, via Pfafstetter codification (Verdin and Verdin, 1999) or by Strahler order (Rodríguez-Iturbe and Valdés, 1979). Other methods that do account for surface characteristics are usually HRU concepts (Winter, 2001; Wagener et al., 2007; Schumann et al., 2000; Winter, 2001) that neglect the allocation of coherently alike regions and their succession within the catchment. Although ACS incorporates a zonal classification that is comparable to an HRU concept, the defined zones do retain the order within the sub-basin in sense of the flow path. The concept is most

10 likely comparable to the concept of Nobre et al. (2011).

More specifically, the ACS-algorithm defines two zone types within each sub-basin to take account for stream network orientated patterns. Since we assumed that the algorithm produces homogeneous natural units the density of zones has been used to define independent physiographical types as part of hydrological landscapes (Winter, 2001). As a measure of physiographical similarity we used the spatial extend of "close to stream" zones, since they indicated the presence of stream

15 network orientated patterns. In this paper only two variables were used and hence only two zone types and four physiographical types were identified. A additional variables are the height above the nearest drainage (Nobre et al., 2011) in order to account for plateaus within the catchment and the hydraulic conductivity of soils.

However, the obtained results only give physiographical similarity of the sub-basins. Future work has to account for the hydrologic system and has to compare the hydrologic similarity to the physiographic similarity. With this intersection the

20 utility of the proposed method for the description hydrological landscapes could be evaluated and elaborated to a catchment classification scheme. In contrast to other schemes (e. g. 2010; Sawicz et al. 2011 and Winter, 2001) the derived landscape types are not derived by statistics about the sub-basin but by its spatial organisation.

\section{References}

Beven, K.: A manifesto for the equifinality thesis, Journal of Hydrology, 320, 18-36, doi:10.1016/j.jhydrol.2005.07.007, 2006.

Blöschl, G., Sivapalan, M., Wagener, T., Viglione, A., and Savenije, H.: Runoff Prediction in Ungauged Basins: Synthesis across Processes, Places and Scales, Cambridge University Press, Cambridge, 492 pp., 2013.

Bossard, M., Feranec, J., and Otahel, J.: CORINE land cover technical guide: Addendum 2000, EEA, Copenhagen, 2000.

Bremicker, M.: Das Wasserhaushaltsmodell LARSIM: Modellgrundlagen und Anwendungsbeispiele, Hochwasserzentralen LUBW, BLfU, LfU RP, HLNUG, BAFU, 2016. 
Hydrol. Earth Syst. Sci. Discuss., doi:10.5194/hess-2016-486, 2016

Dunn, S. M. and Lilly, A.: Investigating the relationship between a soils classification and the spatial parameters of a conceptual catchment-scale hydrological model, Journal of Hydrology, 252, 157-173, doi:10.1016/S00221694(01)00462-0, 2001.

Gharari, S., Hrachowitz, M., Fenicia, F., and Savenije, H. H. G.: Hydrological landscape classification: investigating the performance of HAND based landscape classifications in a central European meso-scale catchment, Hydrol. Earth Syst. Sci., 15, 3275-3291, doi:10.5194/hess-15-3275-2011, 2011.

Grayson, R. and Blöschl, G. (Eds.): Spatial patterns in catchment hydrology: Observations and modelling, Cambridge Univ. Press, Cambridge, 404 pp., 2001.

Güntner, A., Seibert, J., and Uhlenbrook, S.: Modeling spatial patterns of saturated areas: An evaluation of different terrain indices, Water Resour. Res., 40, n/a-n/a, doi:10.1029/2003WR002864, 2004.

He, Y., Bárdossy, A., and Zehe, E.: A catchment classification scheme using local variance reduction method, Journal of Hydrology, 411, 140-154, doi:10.1016/j.jhydrol.2011.09.042, 2011.

Jenson, S. and Domingue, J.: Extracting topographic structure from digital elevation data for geographic information-system analysis, Photometric Engineering and Remote Sensing, 54, 1593-1600, 1988.

Lindström, G., Johansson, B., Persson, M., Gardelin, M., and Bergström, S.: Development and test of the distributed HBV96 hydrological model, Journal of Hydrology, 201, 272-288, doi:10.1016/S0022-1694(97)00041-3, 1997.

Merz, R. and Blöschl, G.: A process typology of regional floods, Water Resour. Res., 39, doi:10.1029/2002WR001952, 2003.

Müller, C., Hellebrand, H., Seeger, M., and Schobel, S.: Identification and regionalization of dominant runoff processes - a GIS-based and a statistical approach, Hydrol. Earth Syst. Sci., 13, 779-792, doi:10.5194/hess-13-779-2009, 2009.

Nobre, A., Cuartas, L., Hodnett, M., Rennó, C., Rodrigues, G., Silveira, A., Waterloo, M., and Saleska, S.: Height Above the Nearest Drainage - a hydrologically relevant new terrain model, Journal of Hydrology, 404, 13-29, doi:10.1016/j.jhydrol.2011.03.051, 2011.

Rodríguez-Iturbe, I. and Valdés, J. B.: The geomorphologic structure of hydrologic response, Water Resour. Res., 15, 14091420, doi:10.1029/WR015i006p01409, 1979.

Savenije, H. H. G.: HESS Opinions "Topography driven conceptual modelling (FLEX-Topo)", Hydrol. Earth Syst. Sci., 14, 2681-2692, doi:10.5194/hess-14-2681-2010, 2010.

Sawicz, K., Wagener, T., Sivapalan, M., Troch, P. A., and Carrillo, G.: Catchment classification: empirical analysis of hydrologic similarity based on catchment function in the eastern USA, Hydrol. Earth Syst. Sci., 15, 2895-2911, doi:10.5194/hess-15-2895-2011, 2011.

Schumann, A., Funke, R., and Schulz, G.: Application of a geographic information system for conceptual rainfall-runoffmodeling, Journal of Hydrology, 45-61, 2000.

Sivapalan, M.: Pattern, Process and Function: Elements of a Unified Theory of Hydrology at the Catchment Scale, in: Encyclopedia of hydrological sciences, Anderson, M. G. (Ed.), Wiley, Chichester, 193-219, 2005. 
Hydrol. Earth Syst. Sci. Discuss., doi:10.5194/hess-2016-486, 2016

Manuscript under review for journal Hydrol. Earth Syst. Sci.

Published: 28 September 2016

(c) Author(s) 2016. CC-BY 3.0 License.

(c) (1)
Hydrology and Earth System Sciences

Discussions

Sivapalan, M., Takeuchi, K., Franks, S. W., Gupta, V. K., Karambiri, H., Lakshmi, V., Liang, X., McDonnell, J. J., Mendiondo, E. M., O'Connell, P. E., Oki, T., Pomeroy, J. W., Schertzer, D., Uhlenbrook, S., and Zehe, E.: IAHS Decade on Predictions in Ungauged Basins (PUB), 2003-2012: Shaping an exciting future for the hydrological sciences, Hydrological Sciences Journal, 48, 857-880, doi:10.1623/hysj.48.6.857.51421, 2003.

5 Skøien, J. O., Merz, R., and Blöschl, G.: Top-kriging - geostatistics on stream networks, Hydrol. Earth Syst. Sci., 10, 277287, doi:10.5194/hess-10-277-2006, 2006.

Soulsby, C., Tetzlaff, D., Rodgers, P., Dunn, S., and Waldron, S.: Runoff processes, stream water residence times and controlling landscape characteristics in a mesoscale catchment: An initial evaluation, Journal of Hydrology, 325, 197221, doi:10.1016/j.jhydrol.2005.10.024, 2006.

10 Sponagel, H. (Ed.): Bodenkundliche Kartieranleitung: Mit 103 Tabellen und 31 Listen, 5., verb. und erw. Aufl, Schweizerbart, Stuttgart, 438 pp., 2005.

Verdin, K. and Verdin, J.: A topological system for delineation and codification of the Earth's river basins, Journal of Hydrology, 218, 1-12, doi:10.1016/S0022-1694(99)00011-6, 1999.

Wagener, T., Sivapalan, M., Troch, P., and Woods, R.: Catchment Classification and Hydrologic Similarity, Geography 15 Compass, 1, 901-931, doi:10.1111/J.1749-8198.2007.00039.X, 2007.

Winter, T. C.: The concept of hydrological landscapes, J Am Water Resources Assoc, 37, 335-349, doi:10.1111/j.17521688.2001.tb00973.x, 2001. 
Hydrol. Earth Syst. Sci. Discuss., doi:10.5194/hess-2016-486, 2016

Manuscript under review for journal Hydrol. Earth Syst. Sci.

Published: 28 September 2016

(c) Author(s) 2016. CC-BY 3.0 License.

Table 1: Results of applications of ACS. Number of ascertained sub-basins, normalized reduction of standard deviation $\sigma$ and density of close to stream zones.

\begin{tabular}{lllllllll}
\hline \multirow{4}{*}{ Catchment } & \multicolumn{7}{c}{ Slope } \\
& No. of & $\alpha_{1}$ (Eq. 7) & $\alpha_{2}$ (Eq. 9) & Close to stream & No. of & $\alpha_{1}$ (Eq. 7) & $\alpha_{2}$ (Eq. 9) & Close to stream \\
& Basins[-] & {$[-]$} & {$[-]$} & zones [\%] & Basins [-] & {$[-]$} & {$[-]$} & zones [\%] \\
\hline Mulde & 79 & 139.3 & 23.0 & 22.3 & 80 & 29,4 & 1,9 & 22,1 \\
Main & 61 & 64.0 & 23.7 & 25.8 & 36 & 58.7 & 10.5 & 26.5 \\
Regen & 32 & 85.6 & 1.8 & 18.8 & 32 & 65.2 & 21.9 & 30.1 \\
Salzach & 36 & 222.3 & 12.2 & 20.9 & 59 & 87.1 & 20.2 & 24.4
\end{tabular}


Hydrol. Earth Syst. Sci. Discuss., doi:10.5194/hess-2016-486, 2016

Manuscript under review for journal Hydrol. Earth Syst. Sci.

Published: 28 September 2016

(c) Author(s) 2016. CC-BY 3.0 License.

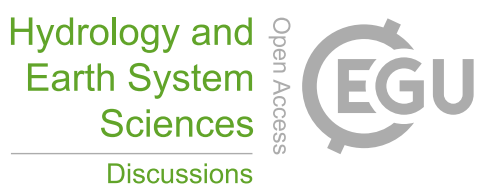

(c) (1)

Table 2: Normalized reduction of standard deviation $\sigma$ for resampled basins

\begin{tabular}{lllll}
\hline \multirow{2}{*}{ Catchment } & \multicolumn{2}{l}{ Pore Volume } & \multicolumn{2}{l}{ Slope } \\
& $\alpha_{1}$ & $\alpha_{2}$ & $\alpha_{1}$ & $\alpha_{2}$ \\
\hline Mulde (res) & 213.3 & 27.3 & 128.5 & 13.4 \\
Salzach (res) & 129.2 & 53.5 & 111.4 & 26.1
\end{tabular}


Hydrol. Earth Syst. Sci. Discuss., doi:10.5194/hess-2016-486, 2016

Manuscript under review for journal Hydrol. Earth Syst. Sci.

Published: 28 September 2016

(c) Author(s) 2016. CC-BY 3.0 License.

\section{Hydrology and Earth System Sciences \\ Discussions}

(c) (i)

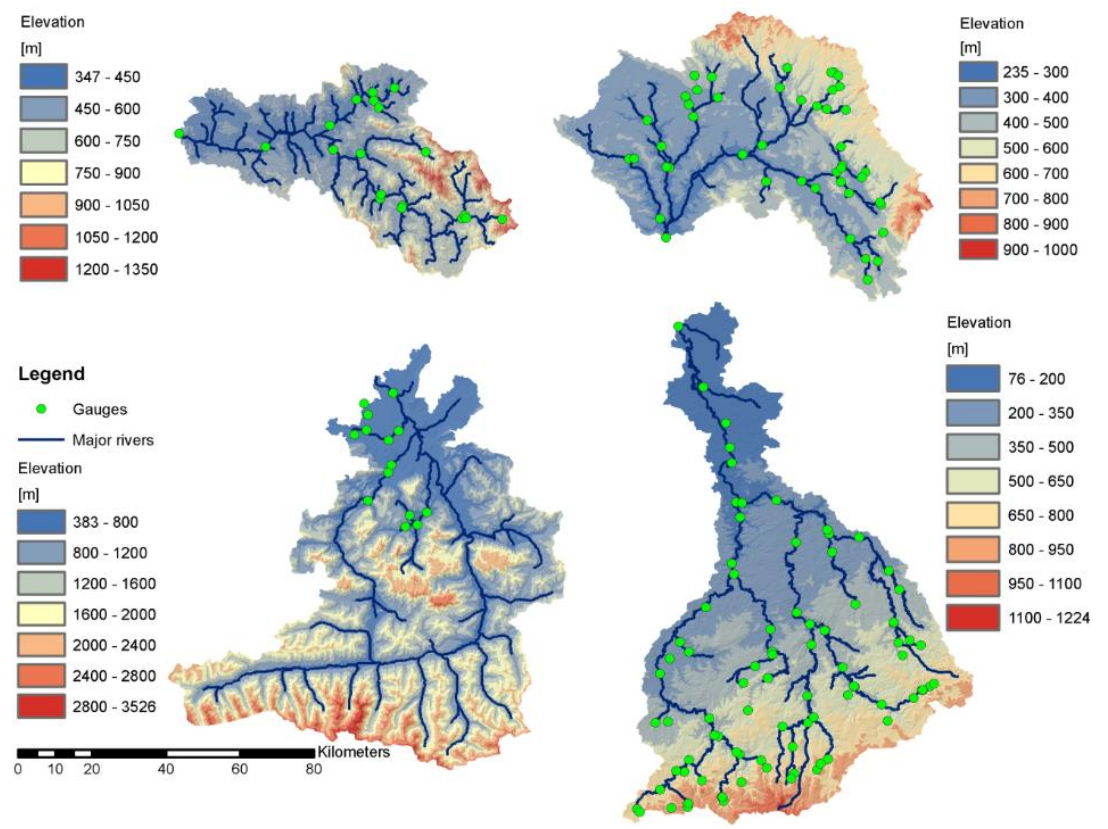

Figure 1: Digital Elevation models of the Regen (upper left) and upper Main (upper right) both in Bavaria, Germany, Salzach (lower left) in Salzburg, Austria, and the Mulde (lower right) in Saxony, Germany.
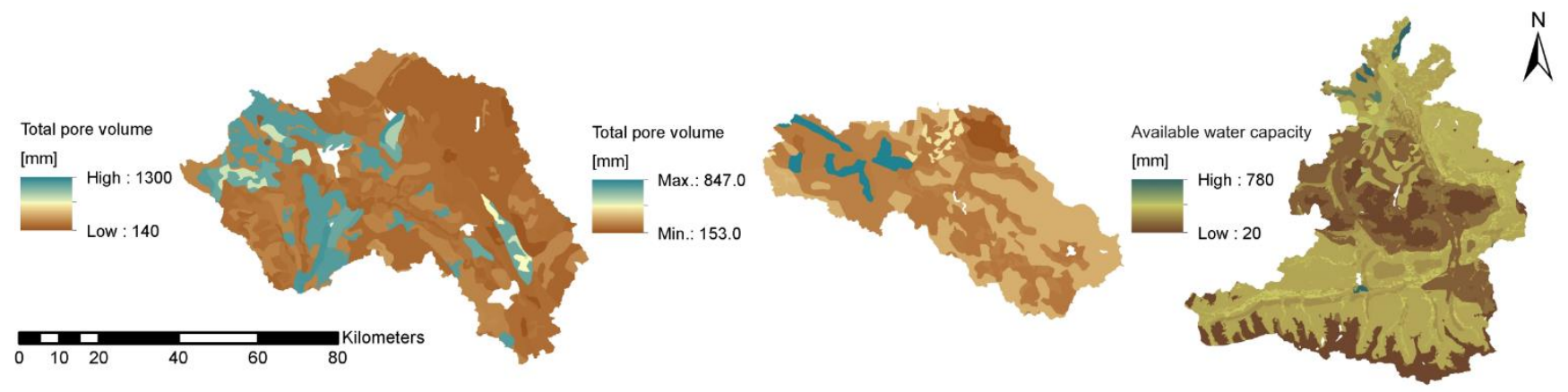

Figure 2: Values of total pore volume in the catchment of Main (left), Regen (centre) and available water capacity for catchment of Salzach (right) 
Hydrol. Earth Syst. Sci. Discuss., doi:10.5194/hess-2016-486, 2016

Manuscript under review for journal Hydrol. Earth Syst. Sci.

Published: 28 September 2016

(c) Author(s) 2016. CC-BY 3.0 License.
Hydrology and Earth System Sciences

Discussions

(c) $\underset{\mathrm{BY}}{(i)}$
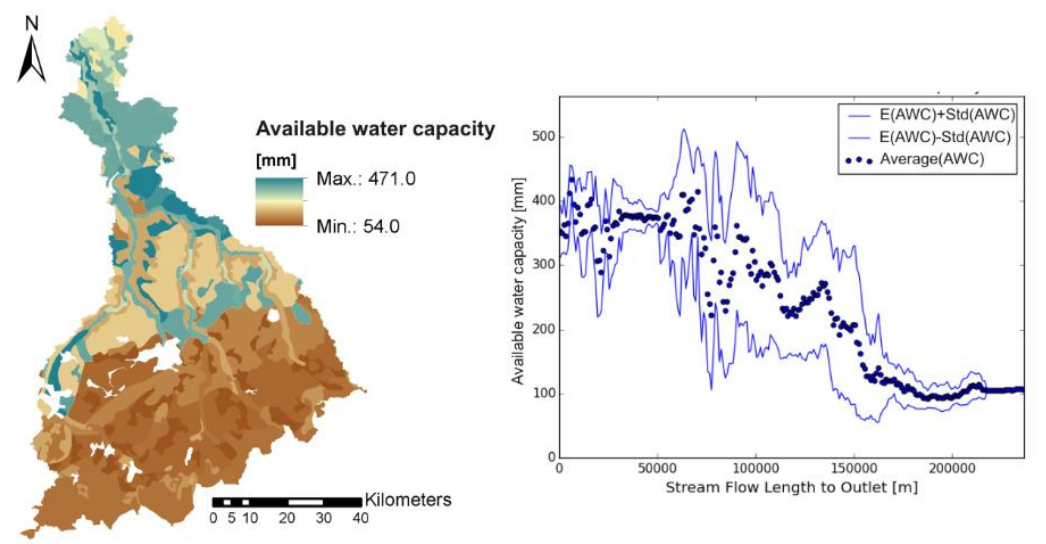

Figure 3: Available water capacity in the Mulde catchment (left) and calculated characteristic structure (right)

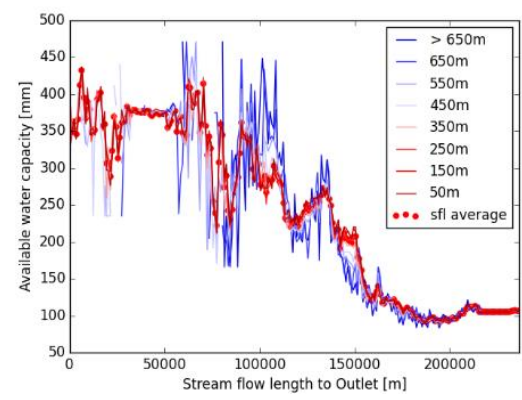

5 Figure 4: Average AWC in OFL classes in the Mulde catchment

Base data of synthetic catchment

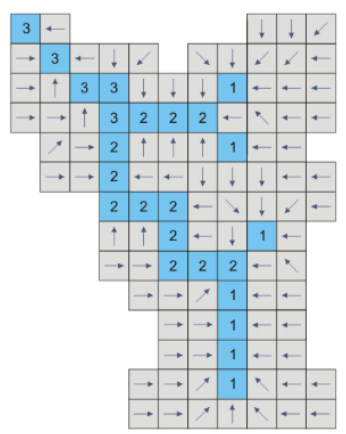

$\square$ Surface cells $\square$ Flow direction

Stream cells 1 Strahler order
Distance classes $(\Delta s=5)$

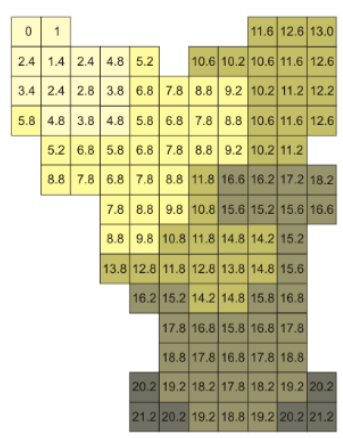

$\square$ Flow length $\square$ Distance Class 3

Distance class $1 \square$ Distance Class 4

Distance class 2 Distance Class 5
Input data

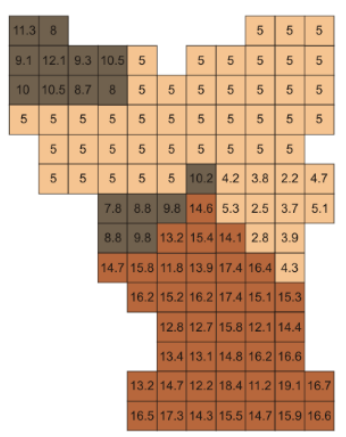

9.8 Data values $\square$ Low values

Mid values $\square$ High values

Figure 5: Flow direction and Strahler order (left), SFL-data and-classes (middle) and example input data (right) 
Hydrol. Earth Syst. Sci. Discuss., doi:10.5194/hess-2016-486, 2016

Manuscript under review for journal Hydrol. Earth Syst. Sci.

Published: 28 September 2016

(c) Author(s) 2016. CC-BY 3.0 License.

(c) (i)

\section{Hydrology and Earth System Sciences \\ Discussions}

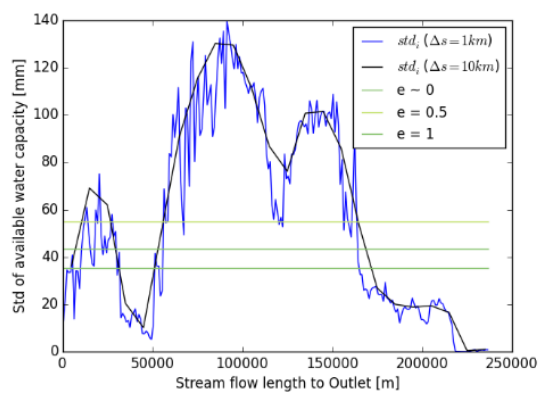

Figure 6: Standard deviation $\sigma$ in SFL-classes and Threshold values $\tau_{S}$ for different values of $e$, in the Mulde catchment

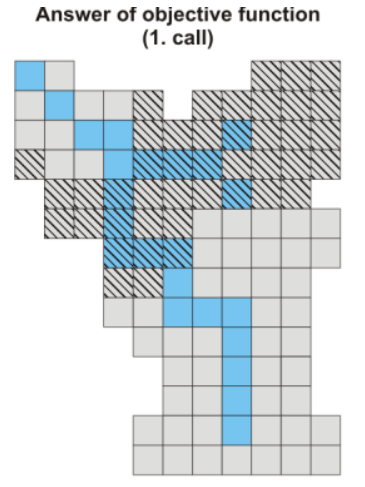

Surface cells $N$ Low variance region

Stream cells

Answer of objective function (2. call)

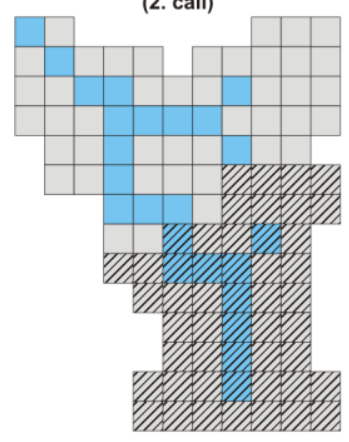

D. High variance region

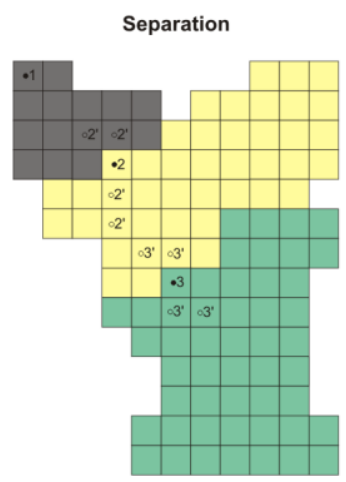

Basin SP(1) - SP

Basin SP(2) $\circ$ possible SP

Basin SP(3)

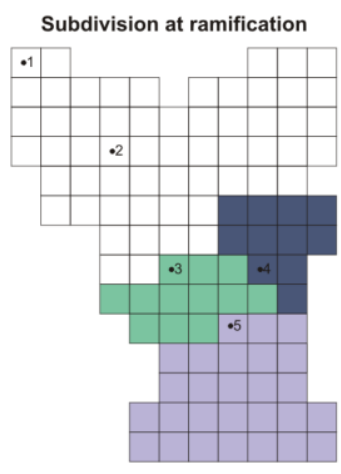

Basin SP(4)

Inactive cells

Basin SP(5)

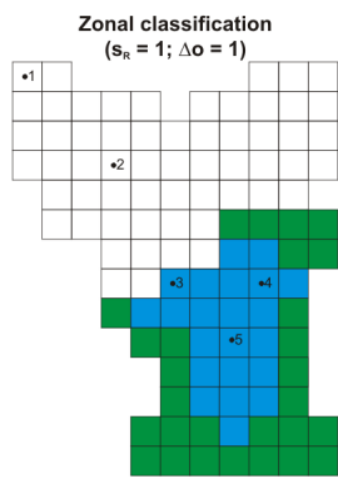

Zone close to stream

Zone far from stream

5 Figure 7: Answers of the objective function (left) and separation (upper right) and subdivision techniques (lower right) in the synthetic catchment 
Hydrol. Earth Syst. Sci. Discuss., doi:10.5194/hess-2016-486, 2016

Manuscript under review for journal Hydrol. Earth Syst. Sci.

Published: 28 September 2016

(c) Author(s) 2016. CC-BY 3.0 License.

\section{(c) (1)}

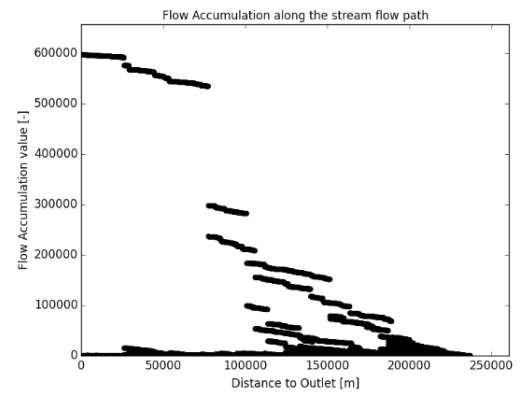

Hydrology and Earth System Sciences Discussions

Figure 8: Characteristic structure of Flow Accumulation in the catchment of the Mulde
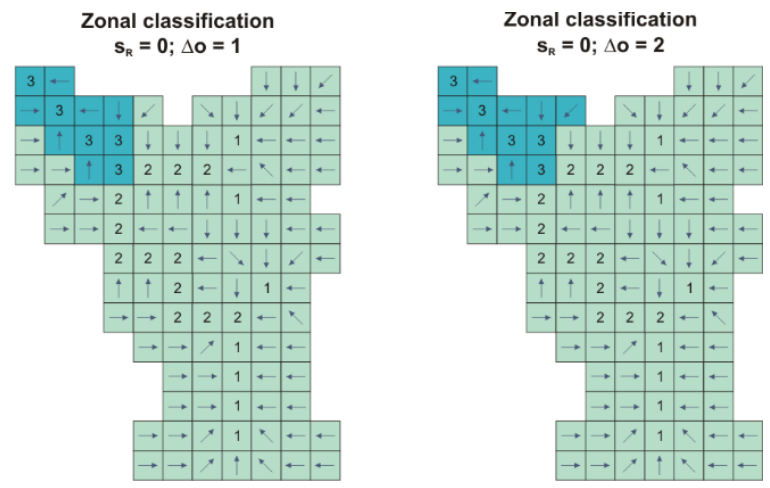

Zonal classification $S_{R}=1 ; \Delta 0=1$

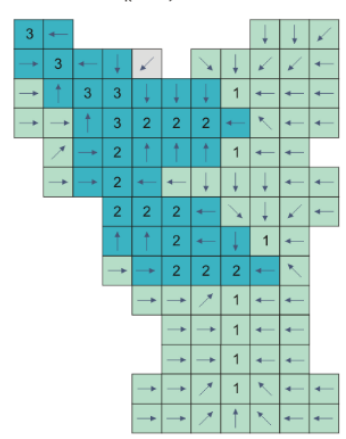

Zonal classification $s_{R}=1 ; \Delta 0=2$

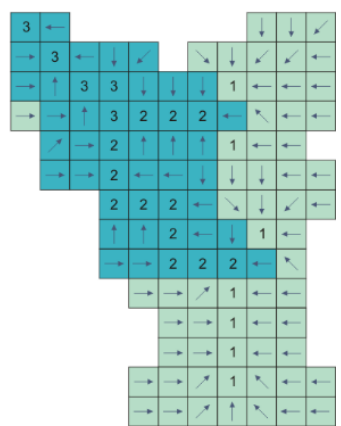

\begin{tabular}{|l|l|l}
$\square$ & Hillslopes & Wetlands \\
\hline 1 & Strahler order & Flow direction
\end{tabular}

Figure 9: Sequence of parameter iteration for entire synthetic catchment. Iteration from upper left to lower right 
Hydrol. Earth Syst. Sci. Discuss., doi:10.5194/hess-2016-486, 2016

Manuscript under review for journal Hydrol. Earth Syst. Sci.

Published: 28 September 2016

(c) Author(s) 2016. CC-BY 3.0 License.

(c) (i)
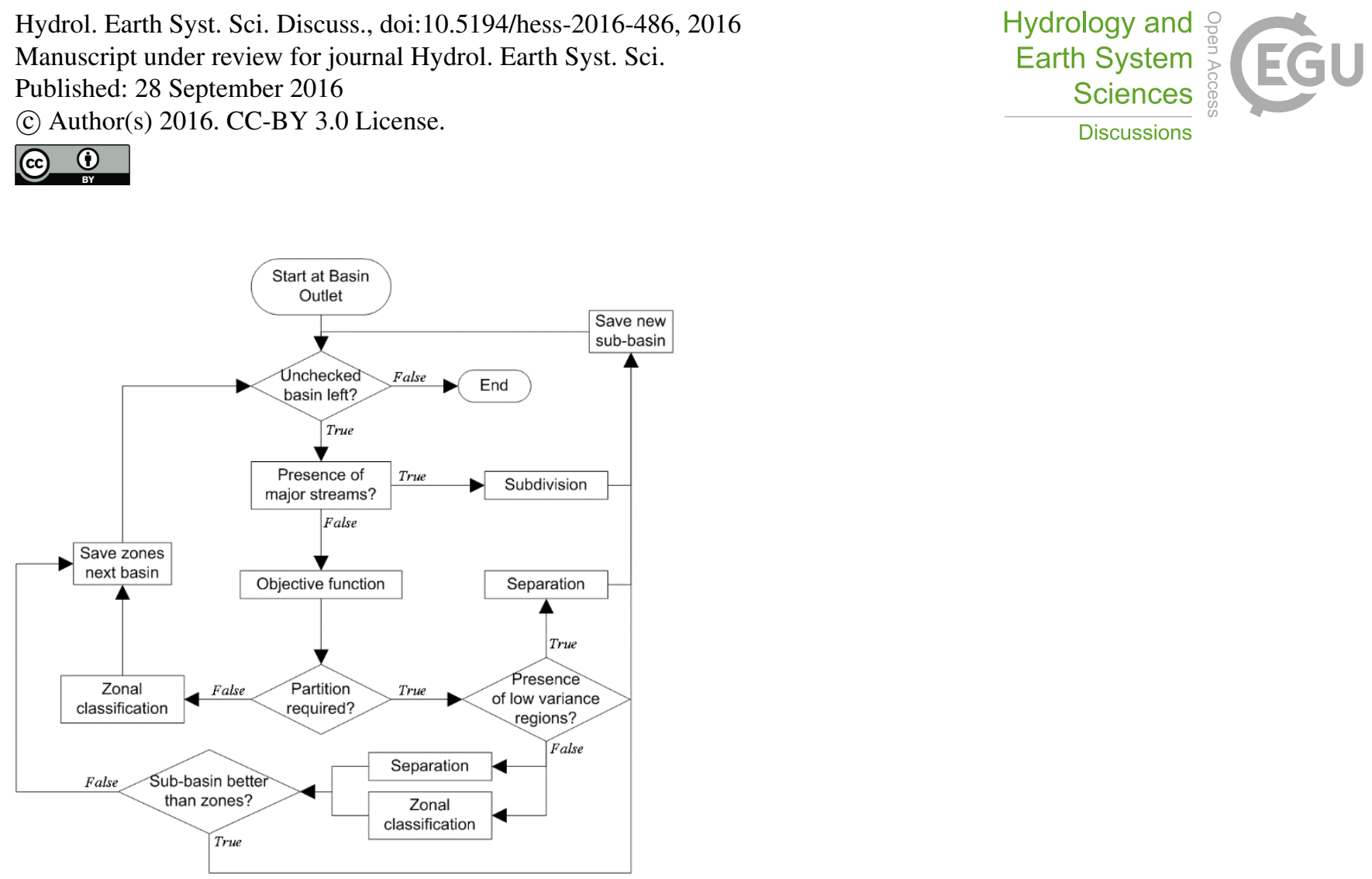

Figure 10: Sequence of the ACS-algorithm 
Hydrol. Earth Syst. Sci. Discuss., doi:10.5194/hess-2016-486, 2016 Manuscript under review for journal Hydrol. Earth Syst. Sci.

Published: 28 September 2016

(c) Author(s) 2016. CC-BY 3.0 License.
Hydrology and

Earth System

Sciences

Discussions

(c)
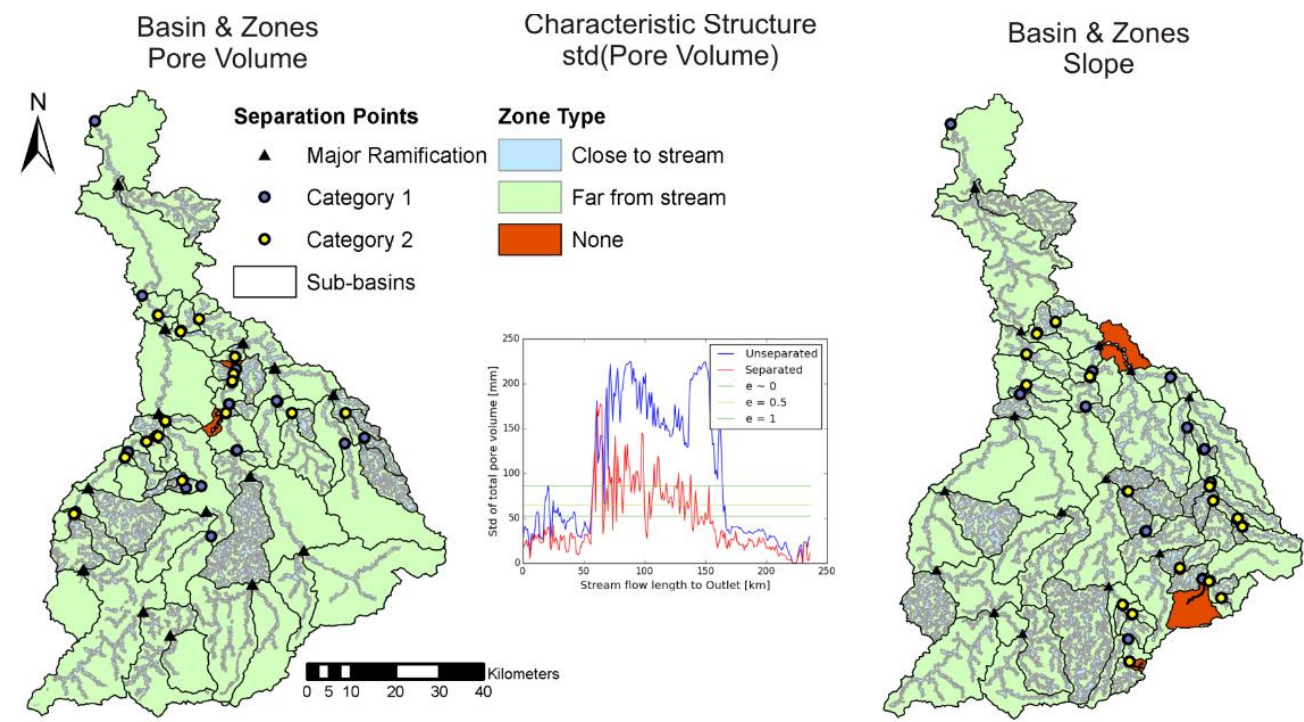

Characteristic Structure std(Slope)
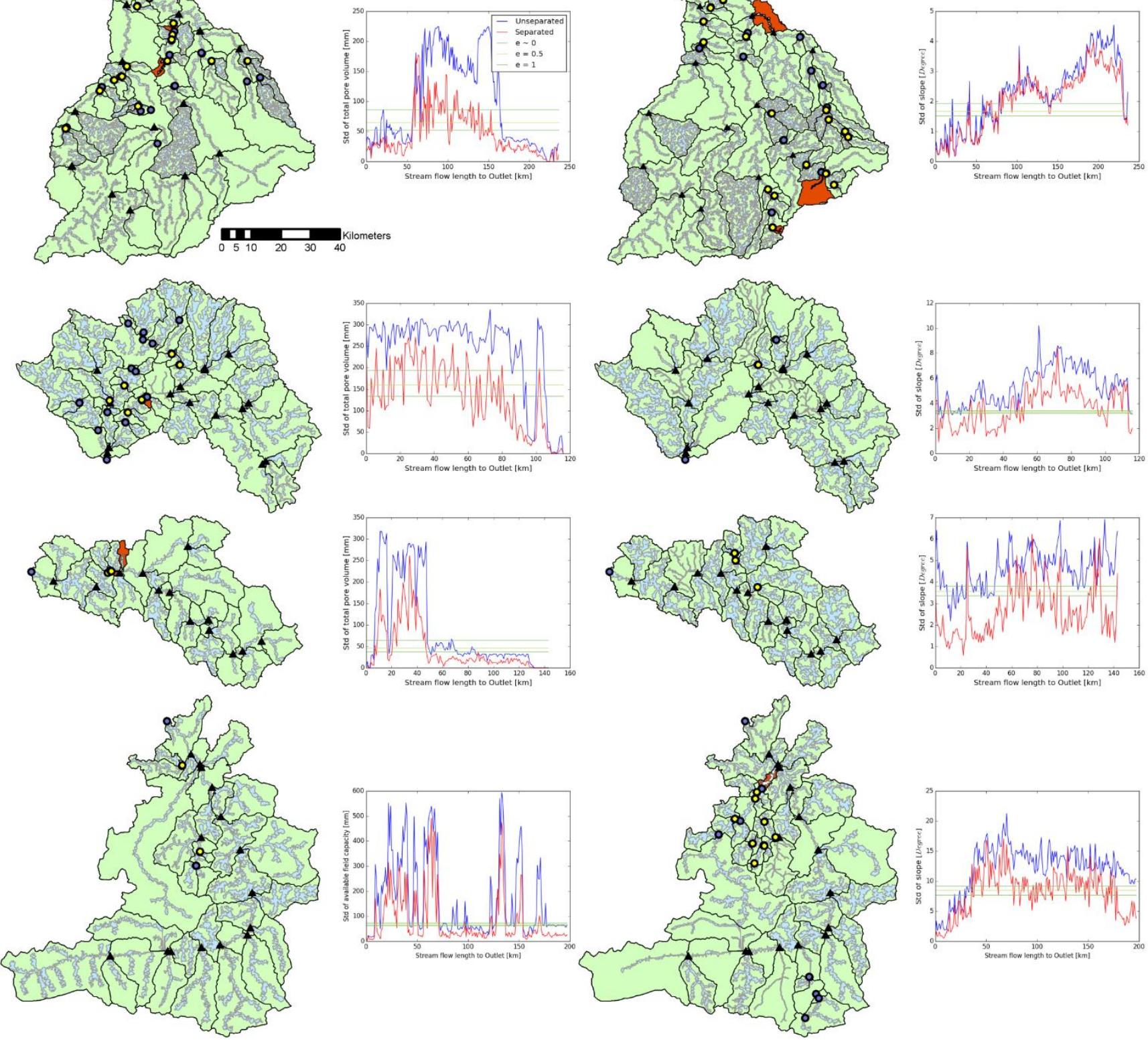

Figure 11: Results of application of ACS for catchments of the Mulde, Main, Regen and Salzach (from top to bottom), sub-basins based on pore volume (left) and slope (right). Comparison of $\sigma(U)$ and $\sigma(S)$ for each application (red and blue lines). 
Hydrol. Earth Syst. Sci. Discuss., doi:10.5194/hess-2016-486, 2016

Manuscript under review for journal Hydrol. Earth Syst. Sci.

Published: 28 September 2016

(c) Author(s) 2016. CC-BY 3.0 License.

\section{Hydrology and Earth System Sciences \\ Discussions}

(c) (i)

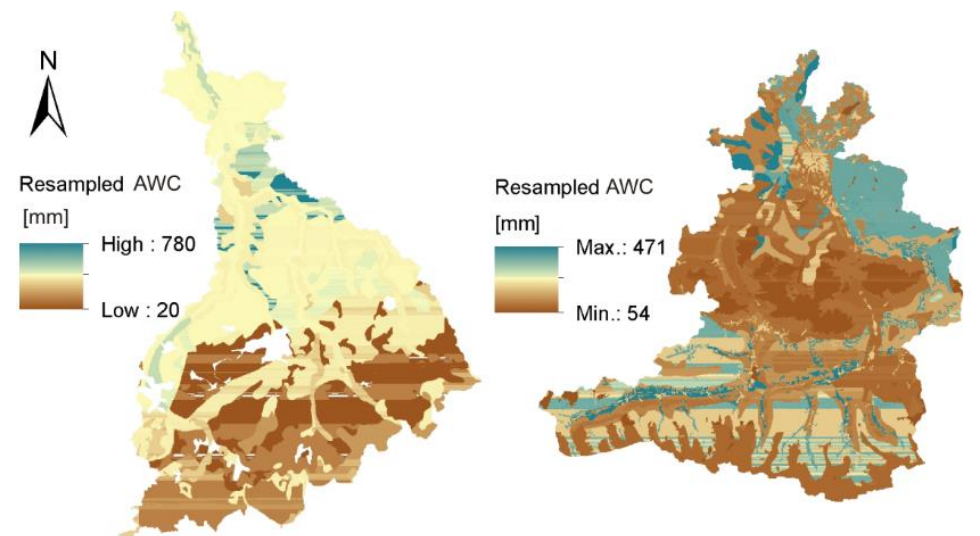

Figure 12: Resampled AWC values for Mulde and Salzach catchment (scale = 1:2500000)

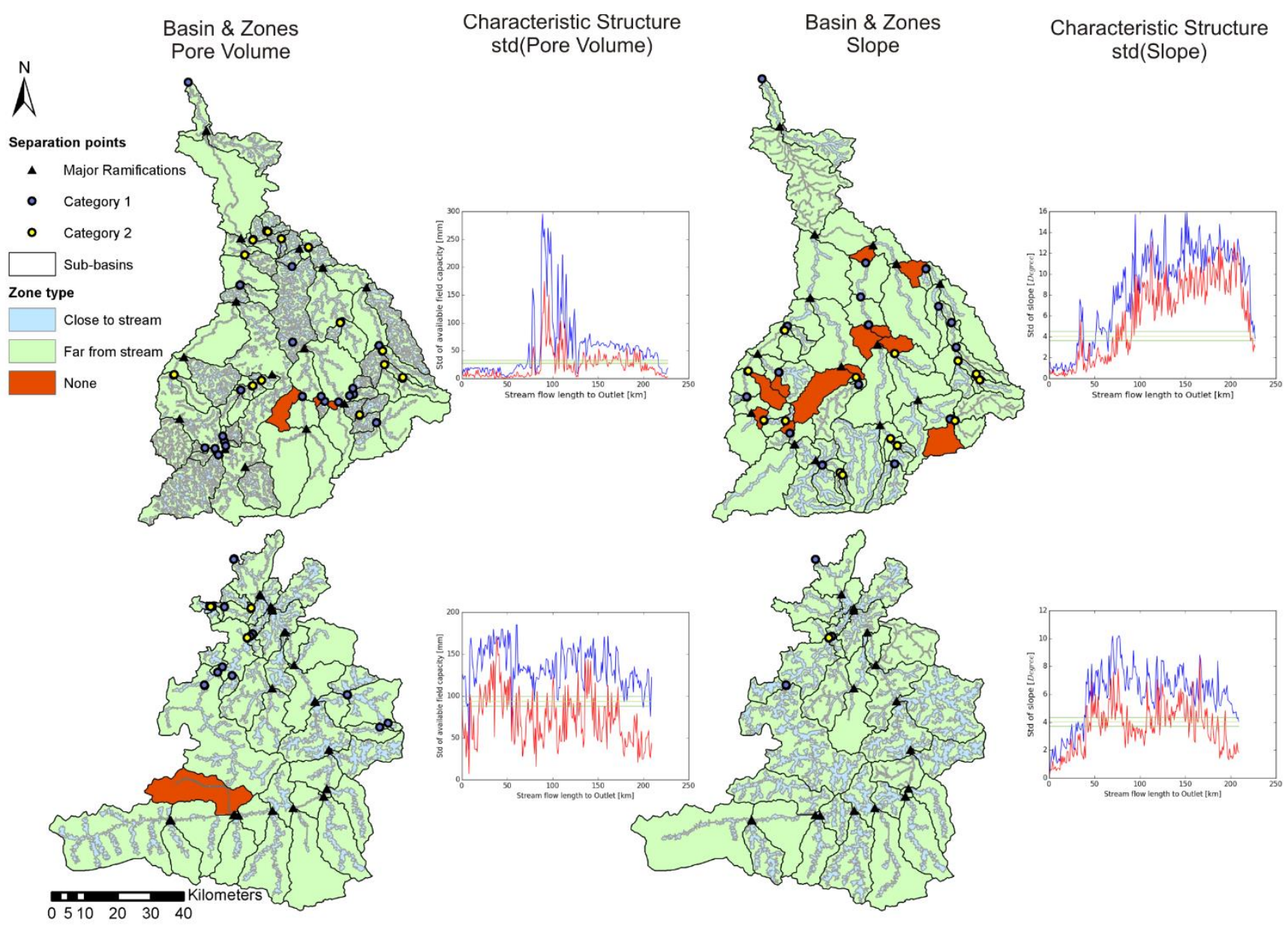

Figure 13: Results of application of the algorithm for resampled catchments of the Mulde and Salzach (from top to bottom), sub5 basins based on resampled pore volume (left) and slope (right). Comparison of $\sigma(U)$ and $\sigma(S)$ for each application (red and blue lines). 
Hydrol. Earth Syst. Sci. Discuss., doi:10.5194/hess-2016-486, 2016

Manuscript under review for journal Hydrol. Earth Syst. Sci.

Published: 28 September 2016

\section{Hydrology and
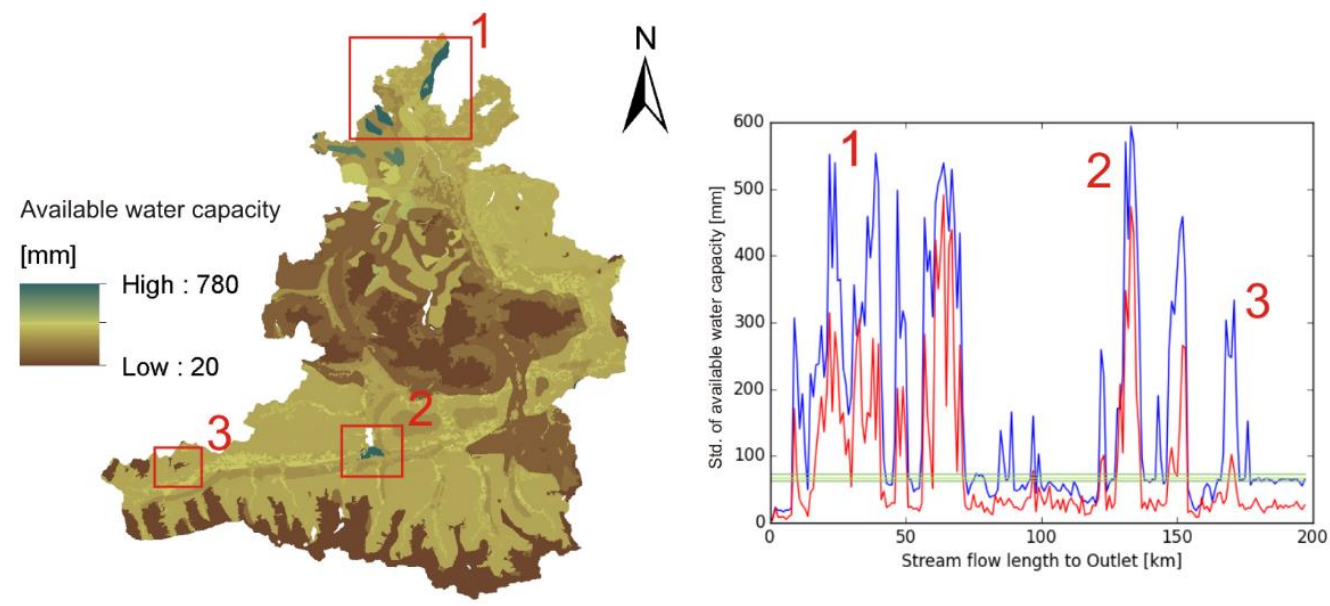

Figure 14: AWC of the Salzach catchment and the characteristic structure of $\sigma(U)$ and $\sigma$ (S). Red marked and numbered areas incorporating high value enclosures

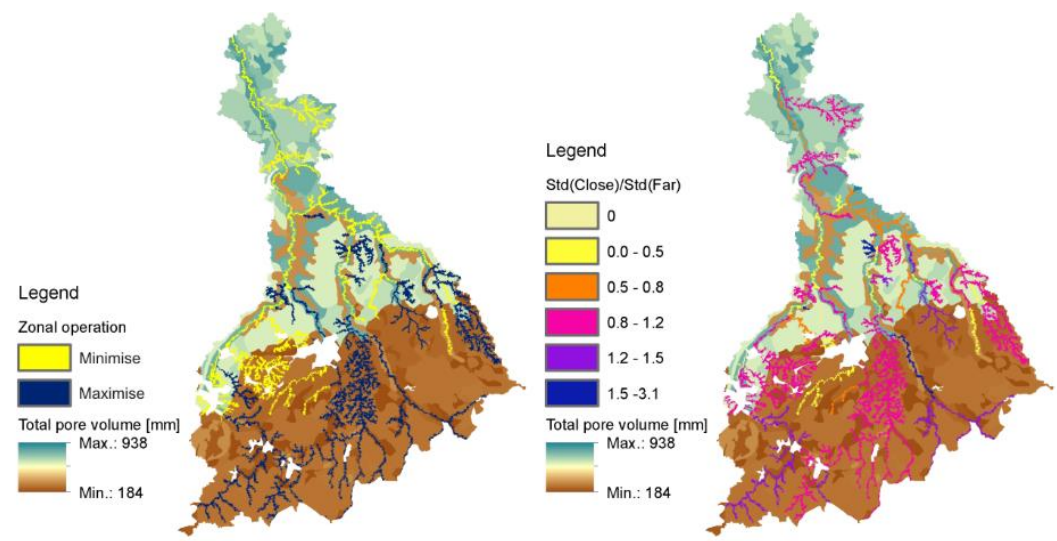

5 Figure 15: Operation of zonal classification (left) and proportion of $\sigma$ of "close to - " and "far from stream" zones (right) in the Mulde catchment 


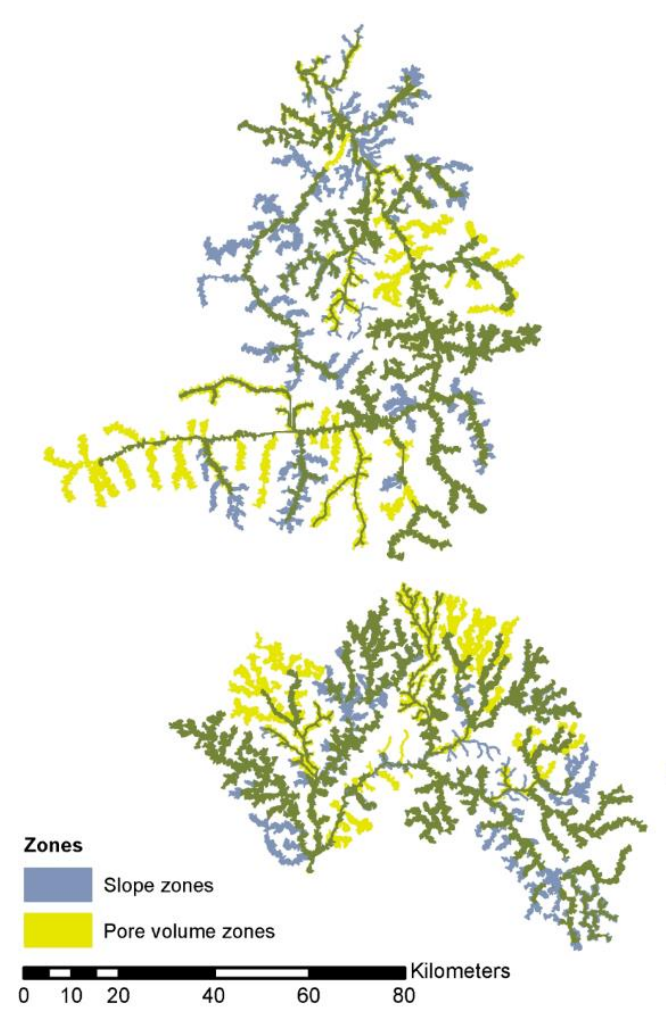

Hydrol. Earth Syst. Sci. Discuss., doi:10.5194/hess-2016-486, 2016

Manuscript under review for journal Hydrol. Earth Syst. Sci.

Published: 28 September 2016

(c) Author(s) 2016. CC-BY 3.0 License.

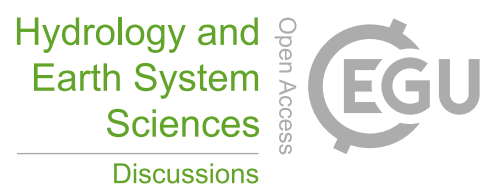

(c) (7)

Figure 16 Left: Overlay of calculated zones for pore volume (blue) and slope (yellow), intersecting zones are shown in green. Right: Map excerpts of slope and pore volume data for indicated areas A and B
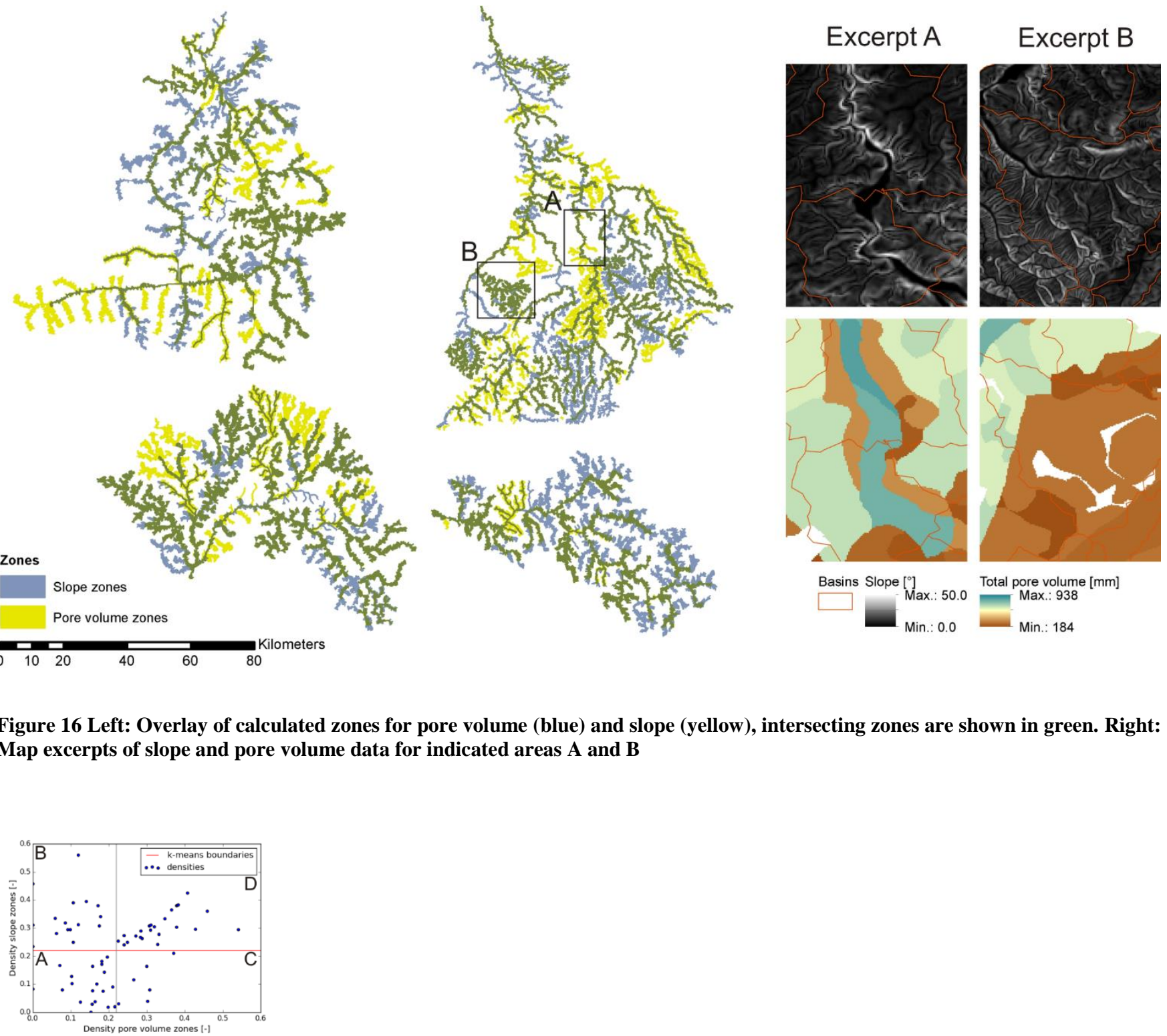

Figure 17: Scatterplot of zone densities and results of k-means cluster analysis for the Salzach catchment and assigned physiographic types (A-D) 
Hydrol. Earth Syst. Sci. Discuss., doi:10.5194/hess-2016-486, 2016

Manuscript under review for journal Hydrol. Earth Syst. Sci.

Published: 28 September 2016

(c) Author(s) 2016. CC-BY 3.0 License.

Hydrology and
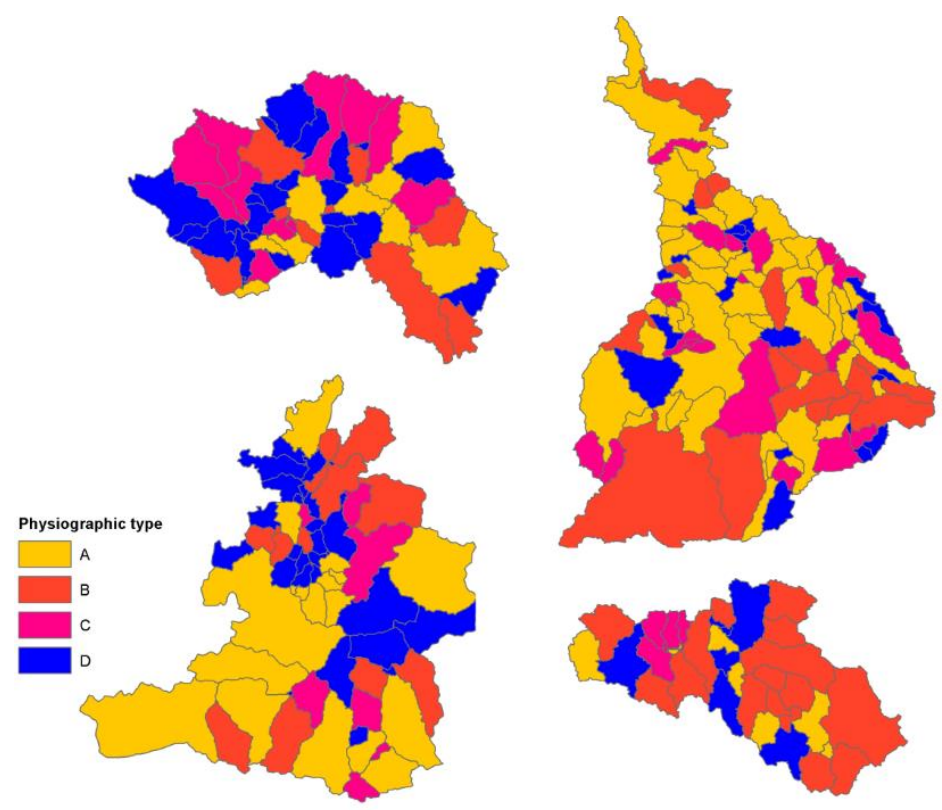

Figure 18: Identified physiographic types in case study catchments 